SOUTHERN BRAZILIAN JOURNAL OF CHEMISTRY

SOUTH. BRAZ. J. CHEM., Vol. 5, No 5, 1997

\title{
SORPTION AND SEPARATION OF Cu(II), Co(II) AND Ni(II) ON 1(4'-AZOBENZYLCELLULOSE)-2-NAPHTOL
}

\author{
TINCA ONOFREI, CECILIA ARSENE and CARMEN MITA \\ "Al. I. Cuza" University Jassy, Faculty of Chemistry, Bd.Mangeron 71,6600 - Jassy, \\ Romania
}

\begin{abstract}
The mechanism of Cu(II), Co(II) and Ni(II) sorption on 1(4'-azobenzylcellulose)2-naphtol has been investigated along with the possible chromatographic separation of the three elements on this chelating sorbent. The data obtained from the dependence of the distribution coefficients on $\mathrm{pH}$ and from isotherms, as well, have evidenced that physical sorption of the three elements is accompanied by chemical sorption, adsorption being predominant for Co(II) and chemosorption for Ni(II) and Cu(II) being much more pronunced for the last element. The modifications in IR and diffuse reflectance spectra lead to the conclusion that chemical sorption involves the formation of chelates. The sorbent may be employed for the separation of $\mathrm{Co}(I I)-\mathrm{Ni}(I I)-\mathrm{Cu}(I I)$ through succesive elution with $0.01 \mathrm{~N} \mathrm{HCl}, 0.1 \mathrm{~N} \mathrm{HCl}$ and $1 \mathrm{~N} \mathrm{HCl}$.
\end{abstract}

\section{KEYWORDS}

Sorption, Separation, Copper, Nickel, Cobalt, Chelating cellulose

\section{RRSUMO}

\footnotetext{
o mecanismo da sorşão de Cu(TT), Co(II) e Ni(II) sobre I(4'-azobenzilcelulose)-2-naftol foi estudado tendo em vista a separacão cromatografifica dos tres íns por este sorbente quelante. Os resultados obtidos para a dependència dos coeficientes de distribuigáo com $p H$ e os isotermas mostraram que que a fisisorgão dos tres elementos é seguida por quimisorgão. - processo de adsorgão quimica predomina para Co(II) e a quimisorsão para Ni(TI) e Cu(IT), sendo mais pronunciada para o CU(IT). As anälises de espectros no infravermetho e de refletância difusa indicam que a sorgão quimica envolve a forma\&ão de quelatos. 0 sorbente pode ser utilizado para a separasão de Co(II)-Ni(II)-Cu(II) através de elucões sucessivas com 0,1 e I. $N$ de $\mathrm{HCl}$.
} 
SOUTH. BRAZ. J. CHEM., Vol. 5, Nº 5, 1997

\section{INTRODUCTION}

Modified celluloses with analytical functional groups as well as other natural and synthetic chelating polymers, combine the properties of selectivity with those of sorbent, being extremely useful in analytical investigations, for both concentrations and separations of elements ${ }^{1-3}$.

Separation of $\mathrm{Cu}(\mathrm{II})-\mathrm{Co}(\mathrm{II})$ - Ni(II) has been performed by various researchers on polyamino-carboxylate ${ }^{4}$-and polyiminodiacetate ${ }^{5}$ - type chelating resin and on cellulose modified by oxime-compounds ${ }^{6}$ and antranylic acid ${ }^{7}$.

The present paper discussed the sorption of $\mathrm{Cu}(\mathrm{II}), \mathrm{Co}(\mathrm{II})$ and $\mathrm{Ni}(\mathrm{II})$ on 1(4'azobenzylcellulose)-2-naphtol as well as the possible chromatographic separation of such elements.

\section{EXPERIMENTAL}

1(4'-azobenzylcellulose)-2-naphtol has been synthesised from PAB-cellulose diazotized and coupled with 2-naphtol in a weakly alkaline medium ${ }^{8}$.

In order to establish the mechanism of $\mathrm{Cu}(\mathrm{II}), \mathrm{Co}(\mathrm{II})$ and $\mathrm{Ni}(\mathrm{II})$ sorption on the sorbent considered for the study, the following determinations have been performed:
a. dependence of the distribution coefficients $\left(\mathrm{K}_{\mathrm{d}}\right)$ on $\mathrm{pH}$, at $25^{\circ} \mathrm{C}$;
b.sorption isotherms at $25^{\circ} \mathrm{C}$;
c. calculation of the apparent free enthalpy;
d. IR spectra of the sorbent both before and after sorption, between $400-4000 \mathrm{~cm}^{-1}$;
e. diffuse reflectance spectra.

The distribution coefficients have been determined by an equilibrium method involving stirring of $\approx 0.2 \mathrm{~g}$ sorbent with $25 \mathrm{~mL}$ standard solution of copper chloride (5.08 $\mathrm{mg} \mathrm{Cu}(\mathrm{II}) / \mathrm{L})$, cobalt chloride $(5.05 \mathrm{mg} \mathrm{Co}(\mathrm{II}) / \mathrm{L})$ and nickel chloride $(5.19 \mathrm{mg}$ $\mathrm{Ni}(\mathrm{II}) / \mathrm{L})$ with a given $\mathrm{pH}$, at constant temperature $\left(25^{\circ} \mathrm{C}\right)$ for one hour. Experimentally, it has been established that the time necessary for attaining the equilibrium is below one hour. The solid phase has been separated through filtration, the equilibrium $\mathrm{pH}\left(\mathrm{pH}_{\mathrm{e}}\right)$ being measured in the aqueous phase. The excess of $\mathrm{Cu}(\mathrm{II})$, $\mathrm{Co}(\mathrm{II})$ and $\mathrm{Ni}$ (II) has been determined in a part of filtrate, by flame atomic absorption spectrometry ${ }^{9}$, on a PERKIN-ELMER 3300 spectrophotometer.

For the isotherms, solutions with concentrations ranging between 0.1-1 $\mathrm{mmole} / \mathrm{L}$ have been employed. The sorption isotherms have been represented in the $\bar{X}_{M}=q / q_{o}-X_{M}=c / c_{0}$ coordinates $\left(\bar{X}_{M}\right.$ - the equivalent fraction of the element in sorbent phase and $X_{M}$ - the equivalent fraction of the element in solution), $q$ and $c$ having the following significance: $q$ - amount of sorbed element (meq/g sorbent); $q_{0}$ maximum sorption capacity (meq/g sorbent); $c$ - concentration of the element left in the solution (meq/mL); $c_{0}$ - initial concentration of solution $(\mathrm{meq} / \mathrm{mL})$.

The IR spectra have been recorded on a SPECORD $71 \mathrm{IR}$ spectrophotometer, while the diffuse reflectance spectra on a VSU-2P spectrophotometer equipped with a device for the study of the solid substances. 
SOUTH. BRAZ. J. CHEM., Vol. 5, N 5, 1997

T. Onofrei, C. Arsene \& C. Mita

\section{RESULTS AND DISCUSSION}

Study of the distribution coefficients dependence on $\mathrm{pH}$ (Figure 1) evidences that, over the $\mathrm{pH}_{\mathrm{e}}=2.9$ and $\mathrm{pH}_{\mathrm{e}}=5.1$ interval an increase of sorption differentiated from one element to another takes place.

On taking $\mathrm{K}_{d}$ as a comparison criteria, the three elements range in the following order of the sorbent's selectivity

$$
\mathrm{Cu}(\mathrm{II})>\mathrm{Ni}(\mathrm{II})>\mathrm{Co}(\mathrm{II}) \text {. }
$$

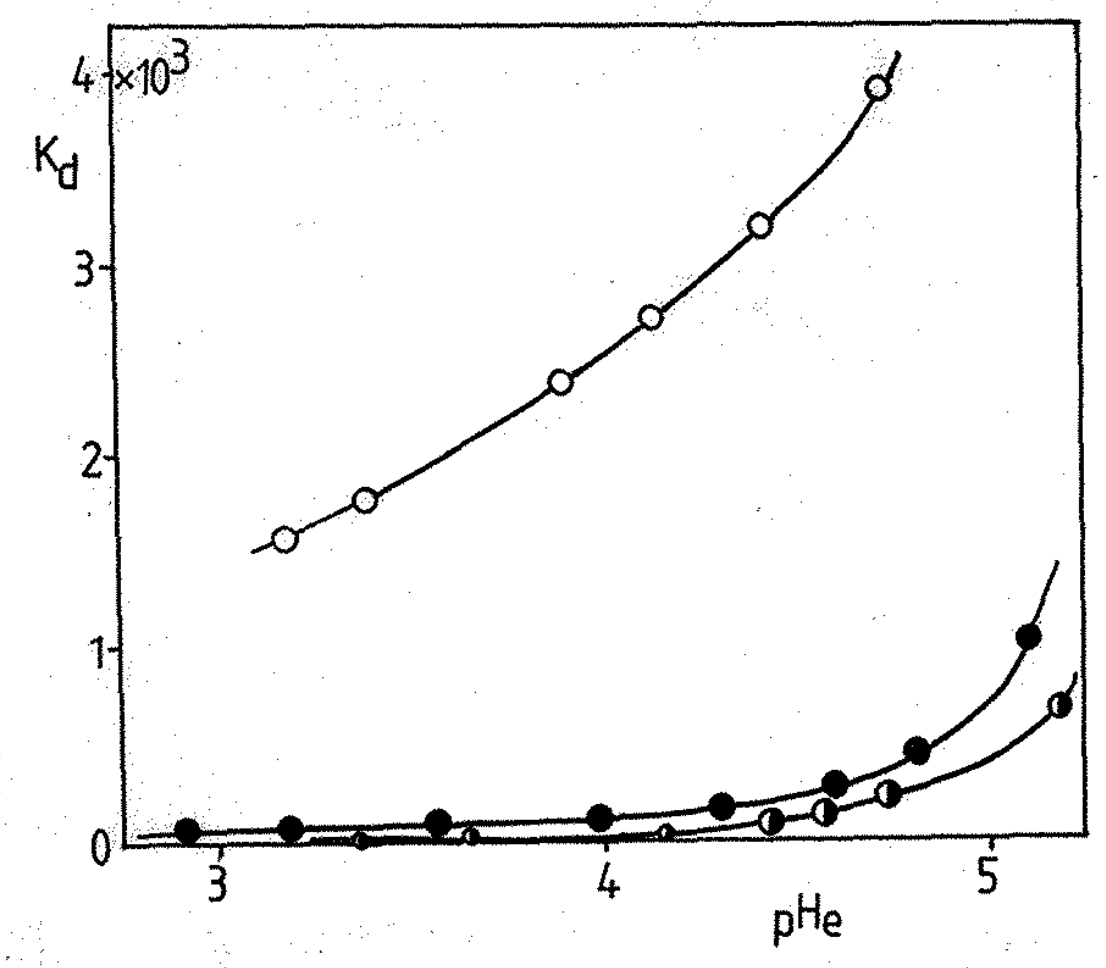

Fig. 1. Dependence of $\mathrm{K}_{d}$ on $\mathrm{pH}$, at $25^{\circ} \mathrm{C}: \mathrm{o}-\mathrm{Cu}(\mathrm{II}) ;-\mathrm{Ni}(\mathrm{II}) ;-\mathrm{Co}(\mathrm{II})$.

For all determinations, it was experimentally observed that the $\mathrm{pH}_{\mathrm{e}}$ value was lower than the $\mathrm{pH}$ of the initial solutions having contacted the sorbent.

Some observations referring to the mechanism of $\mathrm{Cu}(\mathrm{II}), \mathrm{Co}(\mathrm{II}), \mathrm{Ni}(\mathrm{II})$ sorption on 1(4'-azobenzylcellulose)-2-naphtol may be drawn from the study of sorption isotherms. The shape of the sorption isotherms (Figure 2) pleads for a combined mechanism of adsorption and chemosorption, the physical sorption being predominant for $\mathrm{Co}(\mathrm{II})$, while chemical sorption characterizes mainly $\mathrm{Ni}(\mathrm{II})$ and $\mathrm{Cu}(\mathrm{II})$, with highest preponderence for the latter element. 
SOUTH. BRAZ. J. CHEM., Vol. 5, No 5, 1997

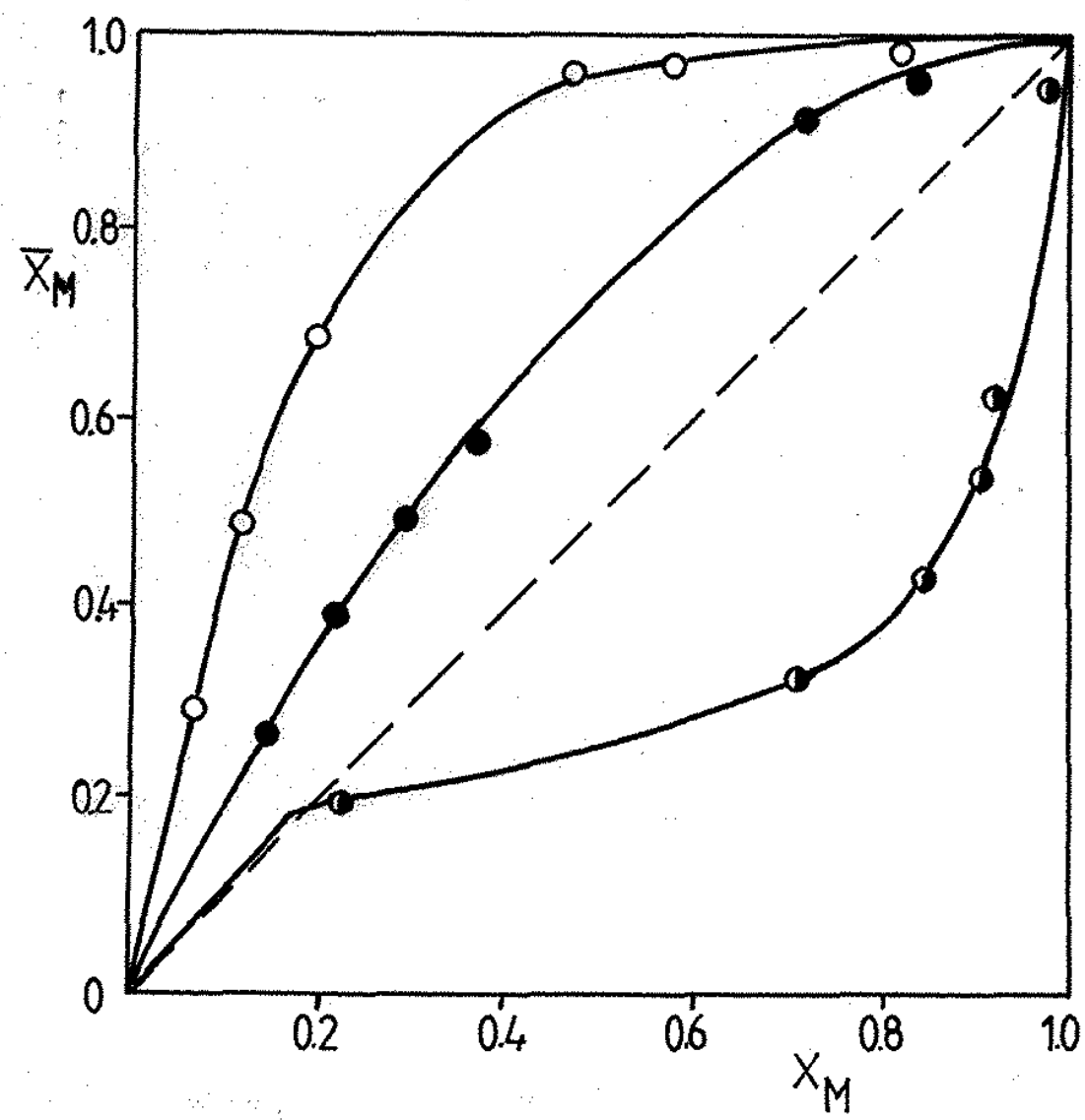

Fig. 2. The sorption isotherms at $25^{\circ} \mathrm{C}: \circ-\mathrm{Cu}(\mathrm{II}) ; \bullet-\mathrm{Ni}(\mathrm{II}) ;-\mathrm{Co}(\mathrm{II})$

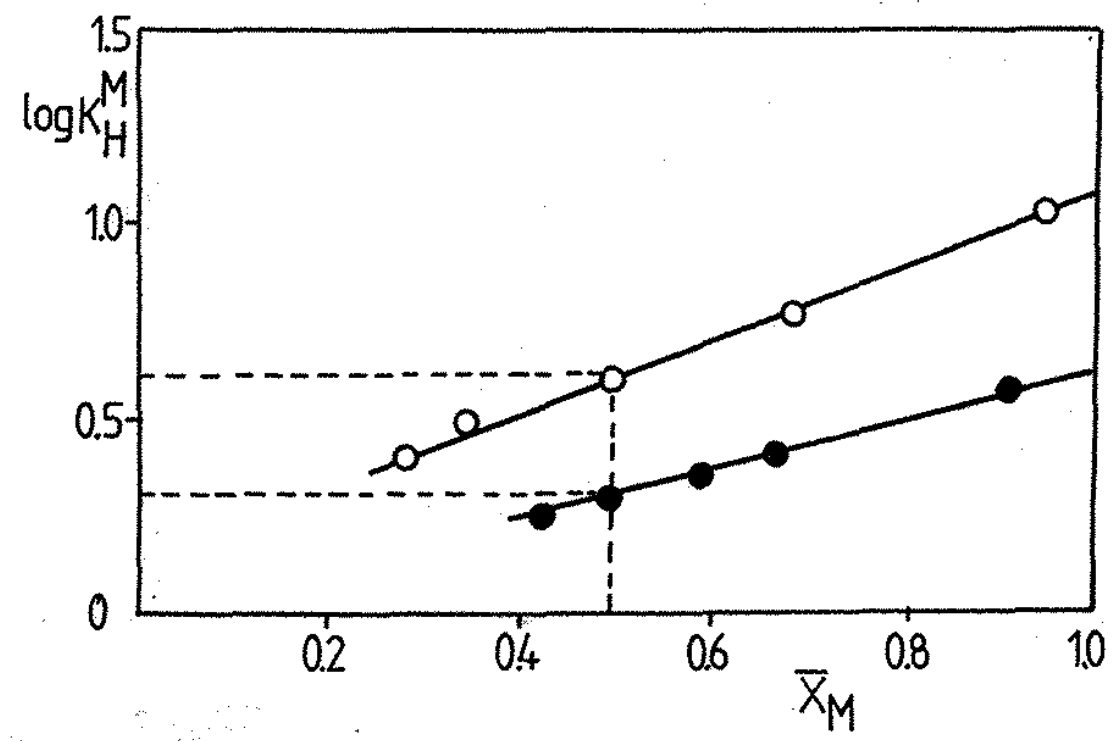

Fig. 3. The evaluation of the exchange reaction constant: $0-\mathrm{Cu}(\mathrm{II})$; $\bullet-\mathrm{Ni}(\mathrm{II})$. 
The data obtained from isotherms have been employed in the determination of the apparent constants of ionic exchange.

For the reaction of ionic exchange

$$
2 \mathrm{H}^{+} \rightleftharpoons \mathrm{M}^{2+}
$$

the exchange constant is:

$$
K_{H}^{M}=\frac{\bar{X}_{M}^{1 / 2} \cdot X_{H}}{X_{M}^{1 / 2} \cdot \bar{X}_{H}}
$$

where $\bar{X}_{M}$ and $\bar{X}_{H}=1-\bar{X}_{M}$ - the equivalent fractions in the sorbent phase; $X_{M}$ and $X_{H}=1-X_{M}$ - the equivalent fractions in the solution phase.

Substitution of the corresponding values from the isotherms permits calculation of $\mathrm{K}$ for each experimental point.

For the evaluation of the apparent constants of ionic exchange, the graph of the $\mathrm{K}_{H}^{\mathrm{M}}=\mathrm{f}\left(\bar{X}_{\mathrm{M}}\right)$ dependence is built while, through interpolations, the $\mathrm{K}_{H}^{\mathrm{M}}$ value is found for $\bar{X}_{M}=0.5$ (Figure 3).

The graph evidences that at $\bar{X}_{M}=0.5$, the values $\mathrm{K}_{\mathrm{H}}^{\mathrm{Cu}}=3.98$ and $\mathrm{K}_{\mathrm{H}}^{\mathrm{Ni}}=2.23$ result.

Based on the apparent constants of ionic exchange determined experimentally, the variation of the apparent free enthalpy may be calculated with relation

$$
\Delta G=-R T \ln K_{H}^{M}
$$

the values $-3421.6 \mathrm{~J} / \mathrm{mol}$ for $\mathrm{Cu}(\mathrm{II})$ and $-1985 \mathrm{~J} / \mathrm{mol}$ for $\mathrm{Ni}(\mathrm{II})$ being found, which pleads for a chemical sorption through ionic exchange, which is more prominent for $\mathrm{Cu}(\mathrm{II})$.

Information on chemical sorption may be obtained from the study of IR and respectively diffuse reflectance spectra.

The IR spectra are quite difficult to be interpreted, due to the minor modifications appearing in both the form and position of the absorption bands and peaks. This is due to the low number of functional groups from the cellulose's macromolecule. In the sorbent's IR spectrum, two small peaks appear at $1600 \mathrm{~cm}^{-1}$ and, respectively $1050 \mathrm{~cm}^{-1}$ attributed to the $-\mathrm{N}=\mathrm{N}$ - group. They disappear after the sorption of $\mathrm{Cu}(\mathrm{II})$ and $\mathrm{Ni}(\mathrm{I})$, or are diminished after $\mathrm{Co}(\mathrm{II})$ sorption which evidences the involvment of the azo group in the formation of chelate - type compounds between the sorbent and cations. At the same time, small modifications appear in the band from $2800-3000 \mathrm{~cm}^{-1}$ attributed to the $-\mathrm{OH}$ groups. This band also includes the vibrations of the -OH groups from cellulose remained unmodified.

The diffuse reflectance spectra are plotted in Figure 4. The sorbent is red, evidencing an absorption maximum at $500 \mathrm{~nm}$, observed as suffering a batochromic shifting after sorption of $\mathrm{Cu}(\mathrm{II})$ at $521 \mathrm{~nm}$, of $\mathrm{Ni}(\mathrm{II})$ at $513 \mathrm{~nm}$ and $\mathrm{Co}(\mathrm{II})$ at $505 \mathrm{~nm}$.

The equilibrium and spectroscopic data led to the conclusion that the physical sorption of $\mathrm{Cu}(\mathrm{II}), \mathrm{Ni}(\mathrm{II})$ and $\mathrm{Co}(\mathrm{II})$ on 1(4'-azobenzylcellulose)-2-naphtol is accompanied by a chemical sorption, the latter being prevalent for $\mathrm{Cu}(\mathrm{II})$ and $\mathrm{Ni}(\mathrm{II})$, and occurs probably by a reaction of ionic exchange with formation of chelates: 
SOUTH. BRAZ. J. CHEM., Vol. 5, N 5, 1997

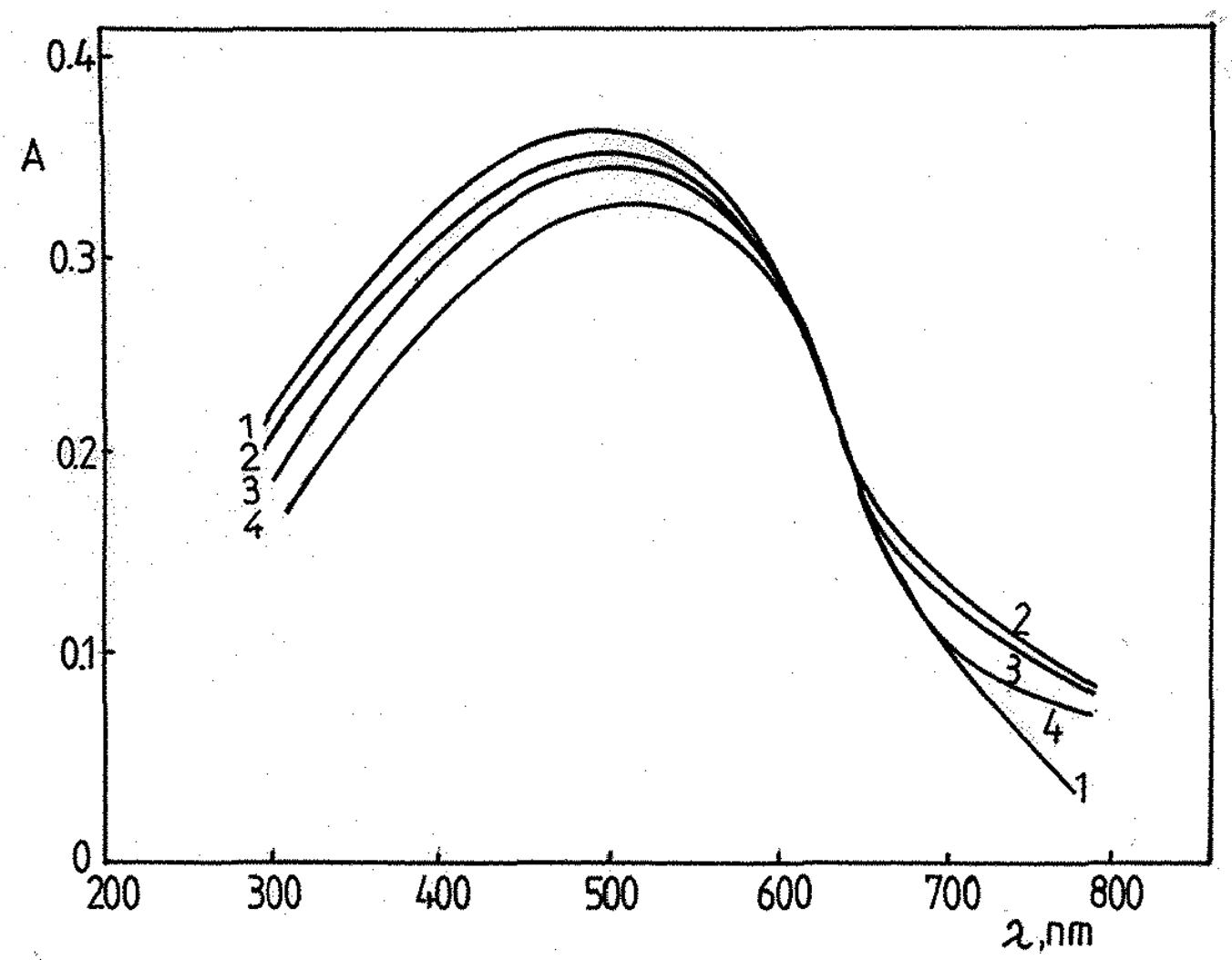

Fig. 4. The diffuse reflectance spectra: 1 - sorbent ; $2-\mathrm{Cu}(\mathrm{I})$-compound; 3 - Ni(II)-compound; 4 - Co(II)-compound.

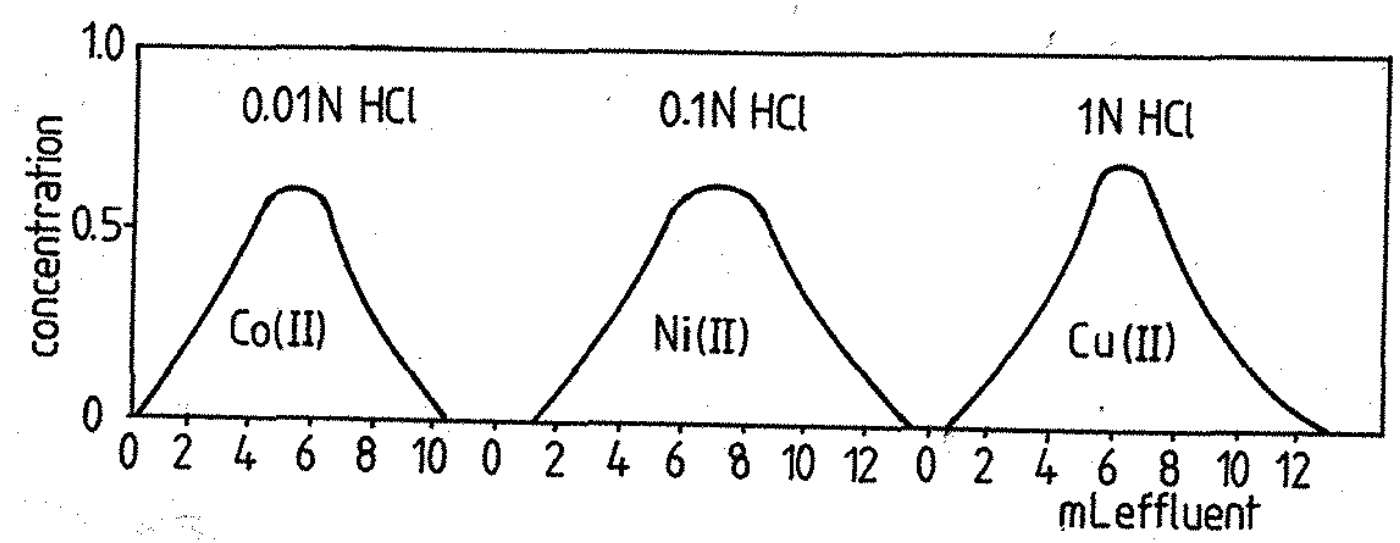

Fig. 5. Separation of $\mathrm{Co}(\mathrm{II})-\mathrm{Ni}(\mathrm{II})-\mathrm{Cu}(\mathrm{II})$. 


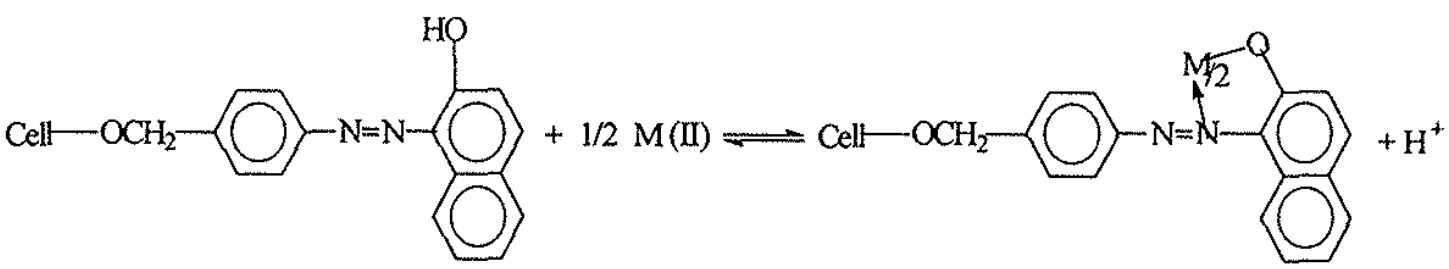

The data obtained under static conditions suggested the possible separation of the three elements on a column filled with 1(4'-azobenzylcellulose)-2-naphtol. A satisfactory separation of $\mathrm{Co}(\mathrm{II})-\mathrm{Ni}(\mathrm{I})$ - $\mathrm{Cu}(\mathrm{II})$ was obtained on a column with a length of $120 \mathrm{~mm}$ and diameter of $20 \mathrm{~mm}$, filled with $4 \mathrm{~g}$ sorbent, by succesive elution with $0.01 \mathrm{~N} \mathrm{HCl}, 0.1 \mathrm{~N} \mathrm{HCl}$ and $1 \mathrm{~N} \mathrm{HCl}$ at the eluent flow rate of $0.1-0.12 \mathrm{~mL} / \mathrm{min}$ (Figure 5).

The obtained results represented in the figure hold true in the domain of a ratio of $1 / 10$ between components (amounts varying from 0.1 to $1 \mathrm{mg}$ ).

\section{REFERENCES}

1. G. V. Myasoedova, O. P. Eliseeva and S. B. Savin, Zhur. Analit. Khim., 26, 2172 - 2187 (1975).

2. G. V. Myasoedova and S. B. Savin, Zhur. Analit. Khim., 37, 499 - 519 (1982).

3. C. Kantipuly, S. Katragadda, A. Chow and H. D. Gesser, Talanta, 37, $491-517$ (1990).

4. Jinfan Zhou and Linmei Yu, Linhua Jianyan Huaxue Fence, 25, 2-5 (1989); Chem. Abstr. 113, 33903b (1990).

5. Jinfan Zhou, Meifang Shi, Linmei Yu, Linmei Chen, Jingyao Ying and Xianyao Lu, Lizi Jiaohuan Yu Xifu, 6, 93- 99, (1990); Chem. Abstr., 114, 258604a (1991).

6. Takehiro Kojima, Takaiuki Sowa and Makoto Sato, Anal. Chim. Acta., 264, 59-64 (1992).

7. C. P. Trivedi, Deepali Jain and Purnima Kapoor, Anal. Lett., 22, 2021-2031 (1989).

8. S. Fisel, T. Ungurenasu - Onofrei and I. Gabe, Anal. Sti.Univ. "Al.I.Cuza" lasi, 11, $51-54$ (1965).

9. *** Analytical Methods for Atomic Absorption Spectrophotometry PERKIN-ELMER, Norwalk, Connecticut, USA (1982), Standard conditions, pp 1-2. 